\title{
RESTORATION OF DEGRADED SODIC SOILS THROUGH SILVIPASTORAL SYSTEMS IN INDO-GANGETIC PLAINS
}

\author{
YASH SINGH${ }^{1}$, Gurbachan Singh ${ }^{2}$, V Mishra ${ }^{3}$, and Sanjay Arora ${ }^{4}$ \\ ${ }^{1}$ Central Soil Salinity Research Institute \\ ${ }^{2}$ Indian Council of Agricultural Research \\ ${ }^{3}$ Central soil Salinity Research Institute \\ ${ }^{4}$ ICAR-Central Soil Salinity Research Institute
}

March 25, 2021

\begin{abstract}
Present study was conducted to analyze the role of silvipastoral systems to improve soil properties for restoration of degraded sodic soils. Ten years old tree species of Acacia nilotica, Casuarina equisetifolia and Eucalyptus tereticornis planted in a highly sodic soil (pH 10.6, EC 1.43 dSm-1 and ESP 89) were used for understory plantation of grass species like Chloris gayana, Panicum maximum and Pennisetum purpureum. Maximum growth and yield of understory grasses was recorded from treatment T4. Among the grass species, the highest nutritive value $(\mathrm{N}, \mathrm{P}, \mathrm{K})$ was recorded in $\mathrm{P}$. purpureum however, highest neutral detergent fiber and acid detergent fiber in treatment T4 and T11 respectively. The N.P, K and Na+ uptake in treatment T4 and T10 was significantly higher over rest of the treatments. A significant improvement in soils physical properties was recorded under treatment $\mathrm{T} 7$ and $\mathrm{T} 4$ which was attributed to reduced sodicity, addition of leaf litter, and increase in microbial activities due to tree and grass roots, better plant growth, and fine root decay. However, improvement in soil chemical properties was recorded under treatment $\mathrm{T} 4$ which may be attributed to more release of $\mathrm{CO} 2$ by grass roots and solublization of CaCO3.The highest MBC and MBP was recorded in treatment $\mathrm{T} 7$ however, highest MBN and dehydrogenase activities were recorded under treatment T4.On the basis of improvement in soil physico-chemical and biological properties in the tree+grass systems, A.nilotica+C.gayana silvipastoral system could be highly ameliorative and biomass producing system for restoration of degraded sodic soils of Indo-Gangetic plains.
\end{abstract}

\section{Hosted file}

Main documents.pdf available at https://authorea.com/users/403960/articles/515279restoration-of-degraded-sodic-soils-through-silvipastoral-systems-in-indo-gangeticplains 